Portland State University

PDXScholar

\title{
Microfinance: the Impacts of a Poverty Reduction Approach and Financial Systems Approach on Poor Rural Households in Vietnam
}

Cardin A. Le

Portland State University

Follow this and additional works at: https://pdxscholar.library.pdx.edu/honorstheses

Let us know how access to this document benefits you.

\section{Recommended Citation}

Le, Cardin A., "Microfinance: the Impacts of a Poverty Reduction Approach and Financial Systems Approach on Poor Rural Households in Vietnam" (2017). University Honors Theses. Paper 454. https://doi.org/10.15760/honors.451

This Thesis is brought to you for free and open access. It has been accepted for inclusion in University Honors Theses by an authorized administrator of PDXScholar. Please contact us if we can make this document more accessible: pdxscholar@pdx.edu. 


\title{
Microfinance: the impacts of a poverty reduction approach and financial systems approach on poor rural households in Vietnam
}

\author{
by \\ Cardin Le \\ Icardin@pdx.edu
}
An undergraduate honors thesis submitted in partial fulfillment of the requirements for the degree of
Bachelor of Arts
in
University Honors
and
Accounting and Finance

Thesis Advisors:

Jacen Greene

Brenda Eichelberger

Portland State University

2017 


\section{Table of Contents}

$\begin{array}{ll}\text { Abstract } & 2\end{array}$

$\begin{array}{lr}\text { Introduction } & 3\end{array}$

Literature Review $\quad 4$

$\begin{array}{ll}\text { Objectives and Hypothesis } & 7\end{array}$

Methodology 18

Development of Microfinance in Vietnam 9

$\begin{array}{ll}\text { Doi Moi } & 9\end{array}$

$\begin{array}{ll}\text { Reform of Microfinance } & 10\end{array}$

Approaches to Microfinance 11

Poverty Reduction Approach $\quad 11$

Financial Systems Approach $\quad 12$

Financial Systems Approach Globally 13

$\begin{array}{ll}\text { Access to Microfinance } & 14\end{array}$

Formal MFIs $\quad 14$

$\begin{array}{ll}\text { Semi-formal MFIs } & 15\end{array}$

Impacts of Access to Credit on Rural Households 16

Data and Measurement 16

$\begin{array}{ll}\text { Summary of Results } & 17\end{array}$

Evaluation of Microfinance on Rural Household 22

$\begin{array}{lr}\text { Conclusions } & 24\end{array}$

Main Findings $\quad 24$

Recommendation $\quad 26$

Further Research $\quad 27$

$\begin{array}{lr}\text { Bibliography } & 29\end{array}$ 


\section{Abstract}

The microfinance industry has evolved from its earliest roots as a social movement to a multifaceted financial services industry for the poor. The aim of this research is to add to the existing literature by exploring the poverty reduction approach and financial systems approach to microfinance and its implications on poor rural households in Vietnam. It does this through analyzing three main areas: (i) a comprehensive assessment of microfinance in Vietnam; (ii) analyzing the advantages and disadvantages of the poverty reduction and financial system approaches; and (iii) evaluating the impact of access to credit on household poverty reduction in rural Vietnam.

It is demonstrated that a wider range of supporting services such as improvements in physical infrastructure, healthcare, education and skill training is necessary to help the poorest out of poverty. The future of microfinance in Vietnam is shifting from subsidized microcredit through large organizations and state development banks to a market-based provision of credit through independent NGOs. This research finds that the market systems approach may increase financial burdens for poor rural households in Vietnam. Pushing back against the commercialization of microfinance is "responsible finance." The global financial crisis in 2008 emphasized the importance of accountability, security, and transparency in financial services. Innovative technologies may help reduce the risk of increasing financial burdens on clients while scaling social impact. 


\section{Introduction}

Microfinance is an umbrella term describing the provision of banking services by poverty-focused institutions (microfinance institutions - MFIs) who serve those that do not have access to mainstream financial service providers. The limited access for the poor can be attributed to the theory of asymmetric information (Alkerlof, 1970) resulting in problems in adverse selection and moral hazards (Mishkin, 2001). Financial institutions must ration credit in cases of excess demand for financial services. Poor and low-income households are seen as new and riskier markets which require a higher cost of screening and monitoring. The poor possess lower educational backgrounds and cannot provide the standard collateral required by the financial institutions. This excludes them from the financial sector and, as a result, they must turn to informal sectors at extremely high costs.

However, microfinance is based on recognizing that the working poor can act as entrepreneurs, and are in fact creditworthy. Microfinance takes a bottom-up approach to development rather than top-down approaches such as debt forgiveness or international aid. It encourages micro-borrowers to improve their situation through their own efforts rather than depending on external development strategies (Deutsche Bank, 2007). These services are aimed at changing the way money is managed, promoting investing, acquiring productive assets, increasing skill levels, and creating new businesses.

Modern microfinance had its roots in micro-lending in South Asia and Latin America in the mid-1970s. The most notable example is the Grameen Bank model of peer group micro-lending in Bangladesh that has been exported to many other countries and copied by other MFIs. It was not until the 1990s that the microfinance environment transformed from a donor-oriented model into formally regulated financial institutions. Policy makers began debating between whether or not to subsidize financial institutions to provide financial services to the poor. This debate has led to two different approaches to microfinance that will be discussed: the poverty reduction approach and the financial system approach (Robinson, 2001, Rhyne, 1998). 


\section{Literature Review}

In recent years, the volume of literature highlighting the need for rural credit in Vietnam has grown significantly. In the article "Access to Finance and Poverty Reduction: An application to Rural Vietnam," Quach Manh Hao argues that credit has a positive impact on poverty reduction; however, better-off households are more likely to access formal financial sectors rather than the very poor households (Quach, 2005). Using an econometric framework and cross-sectional analysis for estimating long-term impact of credit on households based on panel data from household surveys, Quach noted that the positive impacts are small given the high cost of providing financial services to the poor. This indicates that a wider range of supporting services such as improvements in physical infrastructure, healthcare, education and skill training, rather than an emphasis on credit, is necessary to help the poorest out of poverty. Although Quach still thinks the small benefit is worth considering, he argues that the poverty reduction approach has failed to expand outreach on a sustainable basis. In order to attain a sustainable microfinance system, there must be a balance between social and financial goals in microfinance. Quach proposes a mixed approach between the poverty reduction model and the financial system approach. Institutions would follow the objectives of a commercialized microfinance institution with the support of governments and donors in enabling a financial infrastructure and social intermediation.

Some development economics scholars would agree with Quach's argument that aid alone cannot alleviate poverty, and some would even add that it undermines local institutions and creates self-perpetuating lobbies of aid agencies. Two MIT economists, Abhijit Banerjee and Esther Duflo, argue that "there are very few programmes targeted at the poor that have managed to reach so many people" (Banerjee and Duflo, 2012). In their book, Poor Economics, they report on the Spandana program in Hyderabad, India, where 52 neighborhoods were chosen at random to receive micro-credit help and another 52 other neighborhoods were taken as a control group. After eighteen months, evidence showed that microfinance was working but not dramatically because people 
continued to borrow from money lenders at excessively high-interest rates due to the rigid rules and time cost imposed on micro-credit borrowers.

An alternative to borrowing is prior saving; some economists suggest that "micro-saving is poised to become the next micro-finance revolution" (Banerjee and Duflo, 2012). Although others may argue that it is hard for the poor to save because they have no money and a preference for present instead of future consumption. It is more important for the poor to save because this little buffer could shield them from disasters in the future. In the book, Poor Economics A Radical Rethinking of the Way to Fight Global Poverty, two Economics professors at MIT, Banerjee, and Duflo, suggest that it is harder for the poor to stay motivated when their consumptions goals for the savings seem impossibly out of reach. When their motivations are understood it is possible to move the goalpost closer, this may motivate them to start running towards it rather than giving up. Instead of showcasing one-size-fits-all strategies to ending poverty, Banerjee and Duflo highlight the importance of paying careful attention to the motivations and constraints of everyone (the poor, civil servants, taxpayers, and politicians etc.) in order to create policies and institutions that are better designed and less likely to be perverted by corruption or negligence of duty. They argue that impacts may be incremental but they will sustain and build on themselves; this is a start of a "quiet revolution."

In the article, "Is a government micro-credit program for the poor really pro-poor? Evidence from Vietnam," Viet Cuong Nguyen argues that the Vietnam Bank for Social Policy (VBSP) subsidized loans aimed at reducing the poverty rate have not been well targeted at the poor (Nguyen, 2008). Nguyen uses data from the Vietnam Household Living Standard Surveys (VHLSS) conducted in 2002 and 2004 to measure impact by using the instrumental variables regression method that considers two instruments: credit borrowing and distance from a village to a branch. Nguyen also uses the 2002 and 2004 VHLSS panel data and the fixed-effect with instrumental variables regression method that considers the poverty rates of communes. He found that the non-poor accounted for a larger proportion of the participants and they also tend to receive larger 
amounts of credit compared to the poor. Although, similar to Quach's findings, using the three Forster-Greer-Thorbecke poverty measurements (welfare indicator, poverty gap, and poverty severity), Nguyen found that the program has reduced the poverty rate of the participants by significantly impacting the the consumption expenditure per capita and income per capita of the participating households. One aspect that separates Nguyen's research from other literature on microfinance in Vietnam is its focus on welfare.

Srikant Datar, Marc Epstein and Kristi Yuthas take a similar approach on welfare in the article, "In Microfinance, Clients Must Come First," by taking a client-focused approach instead of an institution-focused one. They argue that most MFIs are institution-centered, aiming to serve as many clients as possible by offering a few basic, high-quality, low-cost services. Whereas client-centered microfinance nurtures the profitability of the borrower's' business, and in turn, the client's economic and social well being (Datar, Srikant, Epstein and Yuthas, 2008). They suggest that MFIs should: (i) provide greater services than traditional financial institutions; (ii) offer not only financial products and services, but also financial education, management training, value chain support, and social services; (iii) track how clients use their loans and allocate their profits; (iv) monitor poverty alleviation using measures of income, as well as those of health, nutrition, housing, and education (Datar, Srikant, Epstein and Yuthas, 2008). Marc Epstein and Kristi Yuthas go further into the importance of measurement in the book, Measuring and Improving Social Impacts: A Guide for Nonprofits, Companies, and Impact Investors. This book serves as an effective model for comparing microfinance organizations based on impact rather than strictly numerical results (Epstein and Yuthas, 2014).

Do Xuan Luan and Siegfried Bauer share similar views with other previously mentioned scholars. In the article, "Does Credit access affect household income homogeneously across different groups of credit recipients? Evidence from rural Vietnam," they show that the one-size-fits-all method to scaling up credit is not advantageous and that there is a need for diversity in policy interventions, particularly to 
the poor and ethnic minorities (Luan and Bauer, 2016). The study uses observational data collected from the Vietnam Access Resources Household Survey (VARHS) carried out in 2012 and the impact evaluation framework suggested by Hulme (2000) that uses three paradigms of impact assessment: the scientific method, the humanities tradition and participatory learning and action. Do and Bauer also use Propensity Score Matching which compares the mean outcome of the credit-accessed household group (treatment group) to the credit non-accessed one (control group) in order to examine the distributional impact of rural credit. The findings of this study suggest a connection between income impacts and sources of loans in the research area. They argue that policies should focus on improving the access of ethnic minorities to education and non-farm employment when expanding schemes of rural credit enhance income.

\section{Objectives and Hypothesis}

Despite the recent national economic success in recent years, rural development in Vietnam still faces a number of challenges. These studies agree that microfinance can reduce poverty rates for recipients. However, they also show that MFIs are not targeting the poorest households in accordance with their proclaimed commitments. Scholars such as Quach, Epstein, and Yuthas argue that a wider range of supporting services such as improvements in physical infrastructure, healthcare, education, and skill training, rather than an emphasis on credit, is necessary to help the poorest out of poverty. Yet there are disagreements about the structure and approach of MFIs. Should MFIs be commercialized in order to become self-sufficient and financially sustainable (Quach, 2005)? Or is this a symptom of mission diffusion and drift in a maturing industry (Epstein, 2010)? This study aims at examining the limitations on existing literature by further exploring the poverty reduction approach and financial systems approach to microfinance and its implications on poor rural households in Vietnam. In order to realize this aim, the key objectives of this study are as follows:

- Implement a comprehensive assessment of microfinance in Vietnam. 
- Analyze the advantages and disadvantages of the poverty reduction and financial system approaches and propose whether a commercial or social approach to microfinance is appropriate for Vietnam.

- Analyze the impact of access to credit on household poverty reduction in rural Vietnam.

The main hypothesis for this research is that the microfinance sector in Vietnam is maturing and experiencing a transition to a market systems approach. As a result, the poorest and most disadvantaged groups of credit recipients are not benefiting from credit access alone. This research further assumes the following:

- A wider range of supporting services such as improvements in physical infrastructure, healthcare, education and skill training is necessary to help the poorest out of poverty.

- A market systems approach may increase the burden for poor rural households.

- Innovative technologies may allow for sustainable scaling of social impact.

\section{Methodology}

This study will examine the implications of microfinance on the welfare of poor recipients by analyzing loan purpose, method of lending, income impacts, and sources of loan repayment. Data will come from observational data from the General Statistics Office of Vietnam Published in 2014, the Vietnam Microfinance Survey in 2011, Assessment Reports from the Developing Microfinance Sector in Vietnam, Asian Development Bank Report 2010, and World Bank Reports. A meta-analysis will be conducted by bringing together empirical findings from a range of studies in order to draw on common findings. In addition, annual reports from the Vietnam Microfinance Working Group (MFWG) plays a crucial role as annual reports from many small MFIs could not be obtained. As no formal field study or survey can be conducted, these reports serve as the primary data source that will be used in this study. 


\section{Development of Microfinance in Vietnam}

\section{Doi Moi}

Vietnam has experienced impressive poverty reduction rates within the past 20 years, falling from 58\% in 1993 to 13.5\% in 2014 (World Bank, 2017). This is attributed to the adoption of a comprehensive reform program that transitioned the economy from a planned to market economy in 1986. Vietnam has determined three essential factors to national sustainable development: economic growth in accordance with social equity, poverty reduction, and environmental protection (Luan and Bauer, 2016). Nearly $20 \%$ of Vietnam's population still live below the poverty line. Microfinance services to the poor (those earning less than $\$ 2 /$ day), has been regarded as an effective tool to alleviate poverty and promote development (Yunus, 2007).

According to the World Bank, in Asia and the Pacific region, more than 300 million households experienced limited credit access through both formal and informal sources (World Bank, 2007). This lack of access is regarded as one of the main reasons why poor rural households in developing countries remain poor (Collins et al., 2009). This case is particularly true for Vietnam, as roughly $72 \%$ of the population live in rural areas. The government has implemented major changes to the credit systems aimed at cutting credit rates for the most vulnerable groups of society and reducing poverty rates (Luan and Bauer, 2016).

After the economic reform in 1986, multiple credit sectors began emerging in Vietnam. These sectors include formal, semi-formal and informal sub-sectors that provide the main source of credit for rural households in Vietnam (Nguyen et al., 2011). The formal sectors include commercial banks and social policy banks, such as the Vietnam Bank for Agriculture and Rural Development (Agribank) and the Vietnam Bank for Social Policy (VBSP). Since 2003, Agribank has become the leading commercial bank with the most extensive network of branches and transaction offices across the country. The bank has over 3 million microloan clients and over 5 million micro savers. 
Agribank, however, focuses on high-income customers, non-poor households, and enterprises. As a result, the market for microfinance is shared by VBSP, People's Credit Funds (PCF), and the Microfinance Institutions (Nguyen et al., 2011).

PCFs are financial cooperatives that provide financial services at the commune/ward level. By 2010, 1,042 PCFs operated in nearly $10 \%$ of Vietnam's communes and wards, and have served about 1.7 million members, $50 \%$ of which were poor households. These funds operated on less than $15 \%$ funding from external sources, which mainly came from The Central People's Credit Fund (CPCF). Although Agribank and PCF were widely available across the country to serve low-income rural households, their commercial structure raised concerns from the government about the exclusion of poor households and disadvantaged groups. As regulated by the government in 2002, the Social Policy Bank of Vietnam (VBSP) was separated from Agribank as a non-profit organization focused on providing subsidized loans to poor rural households. VBSP covered 98\% of the communes in Vietnam by 2010.

In the semi-formal sector, approximately $50 \mathrm{MFIs}$ were established either through a credit savings program, mass social organizations or non-governmental organizations (NGOs) from 1990 to 2005 . By late 2009, three MFls had over 40,000 customers with three others ranging from 20,000 to 40,000 customers. These six MFIs held approximately $50 \%$ of all customers in the semiformal sector. Informal sectors consisted of loans from relatives, friends, or private lenders (Nguyen et al., 2011). According to APEC, in 2008 more than $6 \%$ of the poor borrowed from moneylenders, and about $25 \%$ borrowed from friends and relatives (actual numbers may be understated).

\section{Reform of Microfinance}

Microfinance achieved a milestone in $\mathbf{2 0 1 0}$ when for the first time in history, MFIs were recognized as a type of credit institution in the system of credit institutions in Vietnam. This gave MFIs the legal foundation to grow stably alongside other types of credit institutions towards accomplishing socio-economic development objectives 
through poverty alleviation activities in Vietnam (MFWG, 2014). On December 16, 2011, the Prime Minister signed Decision No. 2195/QD-TTg "To build and develop the safe and sustainable microfinance system towards serving the poor, low-income people, micro, and small enterprises in order to contribute to implementing the Party and Government policies on social welfare and sustainable poverty reduction." These measures included: (i) finalizing the legal normative documents to provide guidelines on implementation of the law; (ii) promoting relevant policies to encourage development of microfinance activities; (iii) studying and issuing regulations on development of professionalism-oriented microinsurance activities; $(v)$ finalizing priority credit policy to ensure right targeting to the poor and other policy groups; (vi) studying and issuing policies on microfinance activities diversification.

According to the Asia-Pacific Economic Cooperation (APEC), the future of microfinance in Vietnam can expect a shift from subsidized microcredit through large organizations and state development banks to a market-based provision of credit through independent NGOs (Asia-Pacific Economic Corporation, 2011). More than 5 years have passed since this decision, yet only three MFIs have been officially licensed. Those include: Tinh Thuong One Member Limited Liability (TYM), M7 limited liability microfinance institution (M7-MFI), and Thanh Hoa Fund for Poor women (FPW). This brings up concerns about the current microfinance industry in Vietnam and policies surrounding it.

\section{Approaches to Microfinance}

\section{Poverty Reduction Approach}

The poverty reduction approach aims at providing cheap financial services to the poor through governmental subsidies with a focus on poverty reduction and empowerment. Under this focus, credit is provided to poor borrowers at below-market interest rates and through networks of government agencies such as development banks and donors. The principle goal of the poverty reduction approach is to improve 
the socioeconomic well-being of the poor through poverty reduction by providing both monetary and social support services. This means that lending needs to be based on the expectation that clients will repay the loans and MFIs mandating that all profits be directly re-invested into more poverty reduction campaigns. Muhammad Yunus, one of the leaders of this approach, argues that personal enrichment from the labors of the impoverished is unethical (Carrillo, 2009).

Critics of this approach are concerned about MFIs not being able to meet the excessive demand for financial services from poor households both in outreach and financial self-sufficiency (Robinson, 2001). These MFIs charge enough interest so that they can sustain themselves and expand, but they are ultimately beholden to their customers rather than investors. A disproportionate amount of attention has been paid to measuring financial performance and growth, resulting in a deficiency of data that measures the socioeconomic impact of microcredit on poor clients. Under this approach, the expansion of financial opportunities needs to be coupled with safeguards that protect poor customers from the dangers associated with debt.

\section{Financial Systems Approach}

The financial system approach on the other hand aims at applying commercial finance principles and building a financial intermediation system for the poor without ongoing subsidy. This approach led to an increased recognition of a wider range of financial services such as micro-savings, micro-insurance, and money transfers. The goal of this approach is to reach sustainable microfinance. This describes the commercial microfinance institution's ability to deliver financial services at a rate that enables them to cover all of the costs and risks to generate profits (Hao, 2005). This is also known as the "commercialization of microfinance" (Epstein, 2010).

Some NGOs have converted to publicly-owned institutions through initial public offerings (IPO). Compartamos is one of those companies, with over $\$ 1$ billion in market capitalization, although the company has been criticized for high interest rates for the poor. These profitable MFIs have been highly sought after by venture capital firms and 
private equity groups (Carrillo, 2009). It is becoming increasingly more difficult for MFIs to manage the growing tensions between maintaining focus on poverty alleviation and accommodating the demands of the funders and markets. As Vietnam's microfinance environment continues to change rapidly, where will this balance lie?

\section{Financial Systems Approach Globally}

Vietnam can look beyond its borders to see the implications of the financial systems approach to microfinance. As previously mentioned, Compartamos, a bank in Mexico, was the first microcredit bank in Latin America that went public with an IPO. In order to ensure small loans would increase profit for shareholders, Compartamos received criticism for increasing interest rates and applying radical methods to loan collection. However, after its IPO in 2007 , net profits rose by $28 \%$ in 2008 to $\$ 112$ million. Despite accusations of predatory lending and harmful practices, Compartamos' client base increased by nearly ten-fold between 2002 and 2008 (Carrillo, 2009). Commercialization is a turning-point for microfinance, reflecting a "mission drift" in the motivation of providing financial services for the poor. In recent years, in specific markets (India, Nicaragua, and the U.S. to some extent), there have been issues with clients taking multiple loans from different MFIs and as a result, some low-income clients became over-indebted.

In 2010, more than two hundred people took their own lives after defaulting on loans from MFIs in Andhra Pradesh, India according to reports by the government (Business Insider, 2012). This triggered India's worst microfinance crisis which mirrors the 2008 subprime mortgage meltdown in the U.S. where finance companies targeted cheap and easy loans at homebuyers until the market crashed and borrowers were unable to sell their homes or pay off their debts. There were reports of MFIs such as SKS Microfinance, India's largest MFI who went public in 2010, verbally harassing over-indebted borrowers, forcing them to pawn valuable items, and humiliating borrowers by sitting outside their homes to shame them. Although the causes of over-indebtedness are complex, microfinance institutions share some responsibility, 
especially in the eyes of customers. Consequently, the global financial inclusion industry has heavily focused on promoting "responsible finance" (International Finance Corporation, 2013).

\section{Access to Microfinance}

\section{Formal MFIs}

Formal MFIs are recognized and operate under the law as credit institutions. TYM, M7-MFI, and FPW are currently offering micro lending products under two methods, group and individual lending, with loan durations in short and medium terms. The group lending method is most common: it increases client access to loans and reduces monitoring cost for MFIs, since this cost is transferred to group members. Loan payment has focused helping clients plan and prepare for sources of payments. Although smaller (daily, weekly, or monthly payments) are made against the principal and interest is more costly for MFIs, this helps clients spread repayment into small installments that are less challenging than lump sum payments. As a result, bad loans are maintained at a low rate.

In addition, these formal MFIs have the ability to mobilize resources, particularly voluntary savings, from individual customers and organizations. After being licensed, TYM's total savings balance doubled in the first year, and M7-MFI also experienced similar increases in savings due to mobilization. In March 2013, TYM and M7-MFI launched a pilot insurance service through mutual funds/mutual assistance funds to provide insurance products directly to customers (mainly existing ones). The two models were seen as relatively successful. However, in April 2013, the State Bank of Vietnam deemed it as informal operations and requested an end to the insurance services. M7-MFI signed an agreement on June 28, 2013 with Bao Viet Hanoi, a leading insurance company, which became an official partner.

Besides financial services, formal MFIs also offer some non-financial services. This is a comparative advantage of microfinance organizations over other credit 
institutions. Non-financial services help build relationship and trust between customers and service providers and, as a result, they increase the community development impact of microfinance activities. TYM trains new customers on personal identification skills and basic household economic management skills. For long-time customers, TYM provides knowledge on gender and business, financial management, health care, and clean water and environmental sanitation. In addition, TYM also pays attention to training of center's leaders through annual courses on center management skills and credit disciplines (MFWG, 2014).

\section{Semi-formal MFls}

Normally, semi-formal MFIs evolve from projects or programs supported by foreign organizations. Since semi-formal MFIs do not operate under the regulations of credit institutions, they are limited in terms of offering the comprehensive activities provided by formal MFIs. Aside from credit in the form of cash, MFIs also offer credit such as young animals (cow, chicken, pig, etc.) and materials (cement, brick, tile, animal feed, etc.). Semi-formal MFIs are limited to compulsory savings and cannot mobilize voluntary funds. Depending on each organization's policy, an amount of $1-1.5 \%$ on the loan amount or an absolute amount (3,000 to $10,000 \mathrm{VND})$ is required to be saved per month, with interest paid of about $0.25 \%$ /month (MFWG, 2014).

Despite those requirements, savings mobilization is an important form of source for funding. Semi-formal MFIs' restrictions lead to MFIs depending heavily on an external source of funding such as grants or internal funding through owner's investments. Legal provisions do not allow semi-formal MFIs to directly provide microinsurance services, instead, they are able to act as agents for formal insurance service providers. This has encouraged partnerships between semi-formal MFis such as Women's Union and insurance companies like Manulife, Bao Viet, and Postal Insurance. This creates opportunities for the poor to have access to other services besides credit and increases their ability to protect themselves against risk. This also encourages insurance companies to invest in this market segment that others hesitate 
to pursue due to higher costs and low profits. Non-financial services are limited to semi-formal MFIs with strong sources of funding such as the Capital Ald Fund for Employment of the Poor (CEP) and Dairu. Despite the limited funds and small outreach, these non-financial services have helped semi-formal MFIs gain the trust of customers.

Customers highly evaluate the social benefits of these services: better knowledge, more self-confidence, more participation in community activities, gender equality, and improved life quality (MFWG, 2014).

\section{Impacts of Access to Credit on Rural Households}

\section{Data and Measurement}

The analysis will use secondary data from reports on the microfinance sector issued by the Asian Development Bank (ADB), the World Bank (WB), and reports from microfinance service providers. This will also use the Vietnam Living Standard Surveys from 2002-2008 and data from the Citi Microentrepreneurship program funded by Citi Foundation from 2007-2011 in partnership with the Vietnam Microfinance Working Group (MFWG, 2014). The latter consisted of surveys conducted in the provinces of Hai Duong and Tien Giang. Each selected two districts, one more developed (urban) and one less developed (rural). Each district selected 2-4 communities that hosted the operations of three main microfinance sources. Three main groups will be the focus of this analysis due to their focus on service to the poor. Those institutions include: the Vietnam Bank for Social Policy (VBSP), Central People's Credit Fund (CCF) and People's Credit Funds (PCF), and MFIs.

The questionnaire was similar for clients of all three MFI groups. The customers are interviewed based on retrospectives, comparing their situation before joining the MFI to their current situation. The following findings will be highlighted to evaluate the implications of the poverty reduction approach to microfinance on poor rural households in Vietnam: credit supply of MFIs, number of customer use of product and services, dept of micro-credit service outreach, total value of loans and average interest rates, 
principal payment methods of loans and interest, source of loan repayment, borrowing purpose, client difficulties in paying back loans, and the number of customers borrowing from other institutions. Non-financial findings such as social benefits of client participation in organizations and the specific benefits will also be evaluated.

\section{Summary of Results}

During the surveyed period, the rapid growth of microcredit services for poor families and social policy target groups have mainly come from the increase in VBSP loans consisting of funding sources facilitated by the government through budget allocations, state-owned commercial banks' compulsory reserves and the government's total-guaranteed loans (Table 1).

Table 1. Information on Credit Supply of the MFls in Vietnam

\begin{tabular}{lcccc}
\hline \multicolumn{1}{c}{ Financial Institution } & $\begin{array}{c}\text { Number of Customers } \\
\text { (millions) }\end{array}$ & $\begin{array}{c}\text { Weight } \\
(\%)\end{array}$ & $\begin{array}{c}\text { Outstanding Loan } \\
\text { (million USD) }\end{array}$ & $\begin{array}{c}\text { Weight } \\
(\%)\end{array}$ \\
\hline VBSP (Total) $^{2}$ & 8.1 & $(\%)$ & 4,588 & 46.5 \\
\hline (Of which: credit for the poor) $^{\text {Agribank }}{ }^{b}$ & 3.7 & & 3,240 & \\
\hline PCF $^{c}$ & 3.2 & 23.5 & 3,500 & 35.5 \\
\hline MFI/NGO $^{d}$ & 1.7 & 12.5 & 1,700 & 17.2 \\
\hline
\end{tabular}

Sources: 'Annual Report of VBSP in 2010, 'Annual Reports of Agribank 2010

'Annual Report of PCF; ' ${ }^{\circ}$ nd of 2010 from MFWG

Table 2 shows that out of 960 people in the survey who borrowed from credit institutions, $37 \%$ borrowed from MFIs due to the smaller scale and less capital required. In addition, loan conditions are more flexible than VBSP and PCF.

Table 2. Numbers of Customers Use Products and Services

\begin{tabular}{lccccccc}
\hline \multirow{2}{*}{ Name } & $\begin{array}{c}\text { Whole } \\
\text { Sample }\end{array}$ & \multicolumn{2}{c}{ VBSP } & \multicolumn{2}{c}{ PCFs } & & MFIs \\
\cline { 2 - 8 } & No. of people & No. of people & $\%$ & No. of people & $\%$ & No. of people & $\%$ \\
\hline \hline Borrowing & 960 & 341 & $36 \%$ & 261 & $27 \%$ & 358 & $37 \%$ \\
Savings & 525 & 130 & $25 \%$ & 83 & $16 \%$ & 312 & $59 \%$ \\
Money transfers & 4 & 0 & $0 \%$ & 4 & $100 \%$ & & \\
Voluntary Savings & 2 & & & & & 2 & $100 \%$ \\
Insurance & 13 & 0 & $0 \%$ & 2 & $15 \%$ & 11 & $85 \%$ \\
\hline
\end{tabular}

Source: Vietnam Microfinance Survey Analysis, 2011 by MFWG 
The type of services that customers use the most is savings: 525 out of 960 , or $65 \%$ had savings at an MFI, while a smaller percentage had savings at VBSP and PCF, $20 \%$ and $15 \%$ respectively. The reason for this is because MFIs encourage members to have compulsory savings, with an amount set as a percentage of the loan amount, in order to reduce the loan balance at maturity. Whereas PCF and VBSP interest rates are more attractive for large savings. Figure 1 shows the overall sample use of products and services.

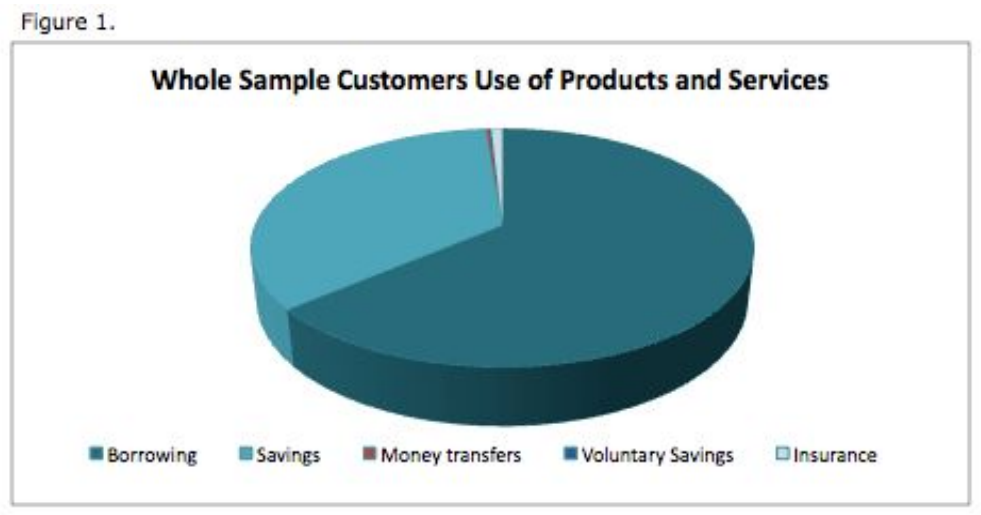

Another area that is important is the depth of microfinance service outreach (Table 3). Out of the 964 people interviewed who took out a loan, 411 had a second loan (over $42 \%$ ). This shows it was relatively easy to obtain access to microcredit for customers who have had their first loan. For VBSP, the average lowest loan amount was VND1 million, and the highest was VND8 milion. The average currency exchange rate for the survey period (2007-2011) is VND18,317 to USD1.

Table 3. The Depth of Micro-Credit Service Outreach

\begin{tabular}{lcccc}
\hline & $\begin{array}{c}\text { Whole } \\
\text { Sample }\end{array}$ & VBSP & PCF & MFI \\
\hline No. of first loans & 964 & 345 & 263 & 356 \\
\hline No. of second loans & 411 & 149 & 130 & 132 \\
\hline $\begin{array}{l}\text { \% of customers having } \\
\text { the second loan }\end{array}$ & 42.43 & 43.19 & 49.43 & 37.08 \\
\hline Total number of loans & $\mathbf{1 3 7 5}$ & $\mathbf{4 9 4}$ & $\mathbf{3 9 3}$ & $\mathbf{4 8 8}$ \\
\hline
\end{tabular}

Source: Vietnam Microfinance Survey Analysis, 2011 by MFWG

VBSP average interest rate was the lowest of the three groups at $0.92 \%$ (Table 4). Their loans ranged from an average of VND14.6 million to the maximum of VND75 million. For MFIs, the total loan amount was much lower, with the lowest loan amount of VND1 
million, and averaging at about VND7 million. This is due to the relatively smaller size of the MFIs and thus the limit to each loan is low. The average interest rate is at $1.14 \% /$ month. The loan purpose for some of the customers surveyed included: production, business, consumer, medical treatment, and loan repayment.

Table 4. Total Value of Loans and Average Interest Rates of Loans

\begin{tabular}{|c|c|c|c|c|}
\hline & & & $\begin{array}{c}\text { Total Value of } \\
\text { loans } \\
\text { (million VND) }\end{array}$ & $\begin{array}{l}\text { Average interest } \\
\text { rates of loans } \\
(\%)\end{array}$ \\
\hline \multirow{5}{*}{ VBSP } & \multirow{2}{*}{$\mathrm{N}$} & Observations & 345 & 343 \\
\hline & & Missing & 0 & 2 \\
\hline & \multicolumn{2}{|l|}{ Mean } & 14.5896 & $0.9179 \%$ \\
\hline & \multicolumn{2}{|l|}{ Minimum } & 1.00 & $0 \%$ \\
\hline & \multicolumn{2}{|l|}{ Maximum } & 75.00 & $9 \%$ \\
\hline \multirow{5}{*}{ PCFs } & \multirow{2}{*}{$\mathrm{N}$} & Observations & 263 & 260 \\
\hline & & Missing & 1 & 4 \\
\hline & \multicolumn{2}{|l|}{ Mean } & 98.3574 & $1.5579 \%$ \\
\hline & \multicolumn{2}{|l|}{ Minimum } & 2.00 & $0.56 \%$ \\
\hline & \multicolumn{2}{|c|}{ Maximum } & 570.00 & $2.18 \%$ \\
\hline \multirow{5}{*}{ MFIs } & \multirow{2}{*}{$\mathrm{N}$} & Observations & 356 & 352 \\
\hline & & Missing & 6 & 10 \\
\hline & \multicolumn{2}{|l|}{ Mean } & 7 & $1.14 \%$ \\
\hline & \multicolumn{2}{|l|}{ Minimum } & 1.00 & $0.65 \%$ \\
\hline & \multicolumn{2}{|l|}{ Maximum } & 34.00 & $7.00 \%$ \\
\hline
\end{tabular}

Source: Vietnam Microfinance Survey Analysis, 2011 by MFWG

There are various forms of interest payments across the credit groups such as: payment at maturity, monthly payments, weekly payments, or irregular payment. The most common principal payment method at VBSP and PCF is payment at maturity, accounting for $77.8 \%$ and $79.13 \%$ of total number of loans respectively (Table 5).

Table 5. Principal Payment Methods of Loans

\begin{tabular}{|c|c|c|c|c|c|c|c|c|}
\hline \multirow{2}{*}{$\begin{array}{r}\text { Method of } \\
\text { Principal } \\
\text { Payment }\end{array}$} & \multicolumn{2}{|c|}{ Whole sample } & \multicolumn{2}{|c|}{ VBSP } & \multicolumn{2}{|c|}{ PCFs } & \multicolumn{2}{|c|}{ MFIs } \\
\hline & $\begin{array}{c}\text { Number of } \\
\text { loans }\end{array}$ & $\%$ & $\begin{array}{l}\text { Number of } \\
\text { loans }\end{array}$ & $\%$ & $\begin{array}{c}\text { Number of } \\
\text { loans }\end{array}$ & $\%$ & $\begin{array}{c}\text { Number of } \\
\text { loans }\end{array}$ & $\%$ \\
\hline At maturity & 700 & $51.02 \%$ & 382 & $77.80 \%$ & 311 & $79.13 \%$ & 7 & $1.43 \%$ \\
\hline Monthly & 407 & $29.66 \%$ & 92 & $18.74 \%$ & 26 & $6.62 \%$ & 289 & $59.22 \%$ \\
\hline Weekly & 192 & $13.99 \%$ & 0 & $0.00 \%$ & 0 & $0.00 \%$ & 192 & $39.34 \%$ \\
\hline Unfixed & 73 & $5.32 \%$ & 17 & $3.46 \%$ & 56 & $14.25 \%$ & 0 & $0.00 \%$ \\
\hline Total & 1372 & $100.00 \%$ & 491 & $100.00 \%$ & 393 & $100.00 \%$ & 488 & $100.00 \%$ \\
\hline
\end{tabular}

Source: Vietnam Microfinance Survey Analysis, 2011 by MFWG

For MFIs, the principal and interest payment are paid on a monthly basis, accounting for $59.22 \%$ of loans, while only $1.43 \%$ of loans are repaid at maturity. This is due to the nature of the customers. MFIs have greater flexibility in regards to repayment methods. Table 6 shows that they are the only ones to consistently offer weekly repayment 
methods (39.34\% of total repayment). This can help clients who wish to break the loan down into smaller payments.

\begin{tabular}{|c|c|c|c|c|c|c|c|c|}
\hline \multirow{2}{*}{$\begin{array}{c}\text { Method of } \\
\text { Interest } \\
\text { Payment }\end{array}$} & \multicolumn{2}{|c|}{ Whole sample } & \multicolumn{2}{|c|}{ VBSP } & \multicolumn{2}{|c|}{ PCFs } & \multicolumn{2}{|c|}{ MFIs } \\
\hline & $\begin{array}{c}\text { Number of } \\
\text { loans }\end{array}$ & $\%$ & $\begin{array}{c}\text { Number of } \\
\text { loans }\end{array}$ & $\%$ & $\begin{array}{c}\text { Number of } \\
\text { loans }\end{array}$ & $\%$ & $\begin{array}{c}\text { Number of } \\
\text { loans }\end{array}$ & $\%$ \\
\hline At maturity & 87 & $6.35 \%$ & 43 & $8.76 \%$ & 42 & $10.69 \%$ & 2 & $0.41 \%$ \\
\hline Monthly & 1035 & $75.55 \%$ & 436 & $88.80 \%$ & 307 & $78.12 \%$ & 292 & $60.08 \%$ \\
\hline Weekly & 192 & $14.00 \%$ & 1 & $0.20 \%$ & 0 & $0.00 \%$ & 191 & $39.30 \%$ \\
\hline Unfixed & 56 & $4.09 \%$ & 11 & $2.24 \%$ & 44 & $11.20 \%$ & 1 & $0.21 \%$ \\
\hline Total & 1370 & $100.00 \%$ & 491 & $100.00 \%$ & 393 & $100.00 \%$ & 488 & $100.00 \%$ \\
\hline
\end{tabular}

Source: Vietnam Microfinance Survey Analysis, 2011 by MFWG

The source of loan repayments can also be traced to four main sources: income, borrowings, grants from other people, and other sources (Table 7). Most of the loans are repaid by incomes earned. This is consistent with data in Table 8 showing the main loan purposes are for production and business, business expansion, or revolving capital. Therefore, the borrowers retain a portion of their business profits to repay the original borrowed capital. Nearly $10 \%$ of of VBSP customers had to borrow more money to pay off their loans compared to less than one percent of PCFs and MFIs customers.

Table 7. Source of Loan Repayment

\begin{tabular}{|c|c|c|c|c|c|c|c|c|}
\hline \multirow{2}{*}{$\begin{array}{l}\text { Source of } \\
\text { Payment }\end{array}$} & \multicolumn{2}{|c|}{ Total } & \multicolumn{2}{|c|}{ VBSP } & \multicolumn{2}{|c|}{ PCFs } & \multicolumn{2}{|c|}{ MFIs } \\
\hline & $\begin{array}{c}\text { Number of } \\
\text { loans }\end{array}$ & $\%$ & $\begin{array}{c}\text { Number of } \\
\text { loans }\end{array}$ & $\%$ & $\begin{array}{c}\text { Number of } \\
\text { loans }\end{array}$ & $\%$ & $\begin{array}{c}\text { Number of } \\
\text { loans }\end{array}$ & $\%$ \\
\hline Owned income & 1297 & $94.60 \%$ & 434 & $88.39 \%$ & 381 & $96.95 \%$ & 482 & $98.77 \%$ \\
\hline Borrowing & 52 & $3.79 \%$ & 48 & $9.78 \%$ & 1 & $0.25 \%$ & 3 & $0.61 \%$ \\
\hline Grant from others & 13 & $0.95 \%$ & 5 & $1.02 \%$ & 6 & $1.53 \%$ & 2 & $0.41 \%$ \\
\hline Others & 9 & $0.66 \%$ & 4 & $0.81 \%$ & 5 & $1.27 \%$ & 0 & $0.00 \%$ \\
\hline Total & 1371 & $100.00 \%$ & 491 & $100.00 \%$ & 393 & $100.00 \%$ & 488 & $100.00 \%$ \\
\hline
\end{tabular}

Source: Vietnam Microfinance Survey Analysis, 2011 by MFWG

Table 8. Borrowing Purpose

\begin{tabular}{lrrrrr}
\hline \multicolumn{1}{c}{ Purpose } & $\begin{array}{c}\text { Number of } \\
\text { loans }\end{array}$ & $\begin{array}{c}\% \text { of total } \\
\text { number of } \\
\text { loans (5) }\end{array}$ & $\begin{array}{c}\text { Average } \\
\text { value of } \\
\text { loans (mil. } \\
\text { VND) }\end{array}$ & $\begin{array}{c}\text { Total value } \\
\text { of loans } \\
\text { (mil. VND) }\end{array}$ & $\begin{array}{c}\text { Percentage } \\
\text { of total } \\
\text { value of } \\
\text { loans (\%) }\end{array}$ \\
\hline Production & 777 & $56.72 \%$ & 17 & 13,428 & $40.43 \%$ \\
\hline Trade/business & 333 & $24.31 \%$ & 42 & 13,910 & $41.88 \%$ \\
\hline Consumption & 59 & $4.31 \%$ & 28 & $1,644.0000$ & $4.95 \%$ \\
\hline Healthcares & 6 & $0.44 \%$ & 46 & 274.00 & $0.82 \%$ \\
\hline Loan payment & 1 & $0.07 \%$ & 60 & 60.00 & $0.18 \%$ \\
\hline Others & $\mathbf{1 9 4}$ & $\mathbf{1 4 . 1 6} \%$ & $\mathbf{2 0}$ & $\mathbf{3 , 9 0 1}$ & $\mathbf{1 1 . 7 4 \%}$ \\
\hline Total & $\mathbf{1 3 7 0}$ & $\mathbf{1 0 0 . 0 0} \%$ & - & $\mathbf{3 3 , 2 1 6}$ & $\mathbf{1 0 0 . 0 0} \%$ \\
\hline
\end{tabular}

Source: Vietnam Microfinance Survey Analysis, 2011 by MFWG 
Customers were also asked if they had difficulties repaying the the loans (Table 9). 260 people out of 962 found it difficult to repay the loans. Out of those who found it difficult, $57 \%$ were customers of VBSP. This could possibly be attributed to the the term of repayment of principal and interest. Longer terms could result in large amount due at maturity, amounts that are inconsistent with the customer's cash flow.

Table 9. With/ Without Difficulties in Paying Back the Loans

\begin{tabular}{lcccc}
\hline & \multicolumn{2}{c}{ Yes } & \multicolumn{3}{c}{ No } \\
\cline { 2 - 5 } & $\begin{array}{c}\text { Number of } \\
\text { people }\end{array}$ & $\%$ & $\begin{array}{c}\text { Number of } \\
\text { people }\end{array}$ & $\%$ \\
\hline VBSP & 145 & $55.77 \%$ & 198 & $28.21 \%$ \\
\hline PCFs & 56 & $21.54 \%$ & 207 & $29.49 \%$ \\
\hline MFIs & 59 & $22.69 \%$ & 291 & $41.45 \%$ \\
\hline Total & $\mathbf{2 6 0}$ & $\mathbf{1 0 0 . 0 0} \%$ & $\mathbf{7 0 2}$ & $\mathbf{1 0 0 . 0 0 \%}$ \\
\hline
\end{tabular}

Source: Vietnam Microfinance Survey Analysis, 2011 by MFWG

Table 10 shows that out of 971 respondents, 130 people borrowed from other places, which may include their relatives or other credit institutions. They consist of 54 MFI customers (42\%), 43 PCF's customers (33\%), and 33 VBSP customers (25\%). Table 10. Number of Customers Borrowing from Other Institutions

\begin{tabular}{lcccc}
\hline \multirow{2}{*}{ Borrow } & \multicolumn{3}{c}{ Yes } & \multicolumn{3}{c}{ No } \\
\cline { 2 - 5 } elsewhere & $\begin{array}{c}\text { Number of } \\
\text { people }\end{array}$ & $\%$ & $\begin{array}{c}\text { Number of } \\
\text { people }\end{array}$ & $\%$ \\
\hline VBSP & 33 & $25.38 \%$ & 312 & $37.10 \%$ \\
\hline PCFs & 43 & $33.08 \%$ & 221 & $26.28 \%$ \\
\hline MFIs & 54 & $41.54 \%$ & 308 & $36.62 \%$ \\
\hline Total & $\mathbf{1 3 0}$ & $\mathbf{1 0 0 . 0 0} \%$ & $\mathbf{8 4 1}$ & $\mathbf{1 0 0 . 0 0} \%$ \\
\hline
\end{tabular}

Source: Vietnam Microfinance Survey Analysis, 2011 by MFWG

This shows that it is very difficult to separate the impact of each credit institution, and there is a big risk of multiple debts in the microfinance sector because organizations do not share information about the borrowers. Although the risk is currently not critical in Vietnam's microfinance sector, there is still the potential risk of default by borrowers who borrow from many different organizations at the same time. Over-indebtedness through multiple loans was one of the main reasons for the recent microfinance crisis in other countries such Mexico and India (Banerjee and Duflo, 2012). As a result, it is important for organizations to pay more attention to multiple debt management 
problems and consider sharing customer information among local organizations.

It is important to consider income, expenditure, and savings when accessing income. Out of 965 customers who provided information, 586 people (60.73\%) believed that their household's income had increased a little after they borrowed. $29.02 \%$ of customers said their income increased a lot, and $10.16 \%$ said their income did not change after borrowing. When breaking this down into the three groups, the ratios of small increases did not change much. However, the percentage of "no increase" in VBSP's customers was relatively high $(21 \%)$ compared to other organizations.

Whereas, $54 \%$ of PCF customers believed that their income increased significantly after they receive capital support from the organization. This could be explained by PCF's average loan size that was relatively high (averaging VND40 million/ customers), compared to VND14.58 million at VBSP and VND6.74 million for MFIs. This suggested a relationship between loan size and an increase in income. One Dong of capital from MFIs brought greater impact to income increases than a similar amount from other organizations.

The changes reported in spending are similar to that of income. Customer spending mostly increased, but the level remains low. PCP's customers were wealthier than VBSP's and MFIs', so their spending is slightly higher. The majority of customers reported no change to their savings. To understand whether customers are using the increase in income and expenditure to invest in business and production or short-term consumption, the survey included assessments of investments. Most customers reported an increase in investment in business and production after participating in the credit institutions. This aligns with the primary purposes of the loans to aid production and business.

\section{Evaluation of Microfinance on Rural Household}

The interview method was based on retrospectives, comparing the customer's situation before joining the MFIs to their current situation rather than using control and 
treatment groups. The survey compared customers' changes in their family's standard of living with their neighbors, accounting for the net difference as an impact of microfinance. Compared to before borrowing, the number of poor and very poor households decreased from $32 \%$ to $17 \%$ and from $7 \%$ to $1 \%$, respectively. With the change in living standards of the poor after participation, the level of impact is very impressive compared to the size of loans and the scale of investments. VBSP has larger volumes of capital investment and support from the government; however, the level of poverty reduction of their customers is only $3 \%$ higher than MFIs. In general, almost all clients of the MFIs agreed that their participation in the MFIs had a positive impact on the living standard of their families. Although there was a difference between those people who believed that the impact was great compared to those who thought it was moderate, no one believed that borrowing from MFIs had no impact or had a negative impact. The questionnaires were designed similarly for clients of all three MFIs groups with no pressure on the clients for a positive response as it was used for research and policy recommendation.

One of the key factors of microfinance is the creation of opportunities and empowering customers particularly women to improve their well-being. Women are empowered to become business owners and have a stronger voice in their households and communities. These opportunities come from offering customers non-financial social support services and involving them in the development and operation of the organization (through group lending programs). Out of the 948 peopled surveyed, all said that borrowing created jobs for their families. 339 people said that they received training from credit institutions, and 636 confirmed that MFIs provided guidance on production, technical and business skills (Table 11). Across these three groups, MFIs have the highest percentage of customers receiving training, guidance and social benefits (37\%). In summary, all 948 received social benefits from the project. 
Table 11. The Impact of Lending and Participation in Organizations

\begin{tabular}{lccccccc}
\hline & Total & \multicolumn{2}{c}{ VBSP } & \multicolumn{2}{c}{ PCFs } & \multicolumn{2}{c}{ MFIs } \\
\cline { 2 - 8 } Other Benefits & No. & No. & $\%$ & No. & $\%$ & No. & $\%$ \\
\hline Job creation & 948 & 336 & $35.44 \%$ & 258 & $27.22 \%$ & 354 & $37.34 \%$ \\
\hline Training & 339 & 89 & $26.25 \%$ & 126 & $37.17 \%$ & 124 & $36.58 \%$ \\
\hline Guidance & 636 & 199 & $31.29 \%$ & 196 & $30.82 \%$ & 241 & $37.89 \%$ \\
\hline Social Benefit & 948 & 336 & $35.44 \%$ & 258 & $27.22 \%$ & 354 & $37.34 \%$ \\
\hline
\end{tabular}

Source: Vietnam Microfinance Survey Analysis, 2011 by MFWG

More specifics social benefits were also identified on the questionnaires. Most customers greatly appreciate the social benefits brought about by microfinance such as improved knowledge, better confidence, increase involvement in community activities, and gender equality and family life quality (Table 12). Although it difficult to quantify these benefits, they play an important part in improving the wellbeing of borrowers.

Table 12. The Specific Benefits of Participation in the Organizations

\begin{tabular}{lccccccc}
\hline \multirow{2}{*}{\multicolumn{1}{c}{ Specific benefits }} & \multicolumn{2}{c}{ Total } & \multicolumn{2}{c}{ VBSP } & \multicolumn{2}{c}{ PCFs } & \multicolumn{2}{c}{ MFIs } \\
\cline { 2 - 8 } & No. & No. & $\%$ & No. & $\%$ & No. & $\%$ \\
\hline More understanding and confidence & 583 & 136 & $23.33 \%$ & 204 & $34.99 \%$ & 198 & $33.96 \%$ \\
\hline More skills to do business & 461 & 129 & $27.98 \%$ & 204 & $44.25 \%$ & 128 & $27.77 \%$ \\
\hline More familly-management skills & 352 & 79 & $22.44 \%$ & 165 & $46.88 \%$ & 108 & $30.68 \%$ \\
\hline More involved in the community activities & 634 & 233 & $36.75 \%$ & 166 & $26.18 \%$ & 235 & $37.07 \%$ \\
\hline Better care for children & 464 & 136 & $29.31 \%$ & 192 & $41.38 \%$ & 136 & $29.31 \%$ \\
\hline Better family health care & 445 & 131 & $29.44 \%$ & 179 & $40.22 \%$ & 135 & $30.34 \%$ \\
\hline Better education of children and family & 485 & 177 & $36.49 \%$ & 195 & $40.21 \%$ & 113 & $23.30 \%$ \\
\hline More responsibility for housework of family member & 281 & 78 & $27.76 \%$ & 127 & $45.20 \%$ & 76 & $27.05 \%$ \\
\hline More dicussions with wife/husband in family issues & 340 & 94 & $27.65 \%$ & 121 & $35.59 \%$ & 125 & $36.76 \%$ \\
\hline Others & 4 & 3 & & 0 & & 1 & \\
\hline
\end{tabular}

Source: Vietnam Microfinance Survey Analysis, 2011 by MFWG

\section{Conclusions}

\section{Main Findings}

The aim of this research is to add to the existing literature by exploring the poverty reduction approach and financial systems approach to microfinance and their implications on poor rural households in Vietnam. Following this aim, the first objective was to conduct a comprehensive assessment of microfinance in Vietnam. This has 
been accomplished by exploring the development of microfinance after Doi Moi in 1986 and after the reforms in 2010, when it was recognized under the law as a type of credit institution. With Decision No. 2195/QD-TTg signed in 2011, the future of microfinance in Vietnam is shifting from subsidized microcredit from large organizations and state development banks to a market-based provision of credit through independent NGOs.

The second aim of this research is to identify and evaluate the two different approaches to microfinance as a result of this shift: (i) Muhammad Yunus' poverty alleviation approach; and (ii) a commercialized, for-profit, financial systems approach. The poverty alleviation approach does not require collateral and charges low interest (the cost of funds at the market rate plus a low margin). The financial systems approach is geared towards charging higher interest rates in order to maximize profits and increase investor and shareholder appeal. The central issue involves defining the purpose of microfinance: should it strive to alleviate poverty or to expand financial services? Looking beyond Vietnam to the global microfinance industry, examples in Mexico and India show the potential risk involved in commercializing microcredit. Although capital and outreach may be expanded, the risk of bad loans and over indebtedness of the poor may result.

The next aim is to analyze the impact of access to credit on household poverty reduction in rural Vietnam. Rural households have accessed credit institutions through formal and semi-formal MFIs. Formal MFIs are licensed with the SBV and have larger capital and more comprehensive services. Nevertheless, due to the unregulated nature of semi-formal MFIs, they can offer diversified features based on changing customer needs. Apart from the improved access, non-financial services sets MFIs apart from formal credit institutions. The social benefits of these services are highly valued by customers and gain their trust. This is proven by the survey data on social benefits (Table 11). This also proves the first hypothesis that access to credit alone cannot increase poverty reduction. A wider range of supporting services such as improvements in physical infrastructure, healthcare, education and skill training is necessary to help the poorest out of poverty. 
The evidence also supports the final hypothesis that the market systems approach may increase the burden for poor rural households. Commercialized MFIs accomplish the goal of outreach. But when analysts and policymakers model economic growth around the free-market with the intention of increasing productivity and efficiency, there is overwhelming evidence that an additional consequence of such pursuits in Mexico has been both the expansion of poverty and the widening of inequality. Yunus supports the idea behind capitalism: "The economic system must be competitive..." as it is "the driving force for all innovation, technological change, and improved management" (Yunus, 2003). It is essential, however, to keep in mind that poverty reduction is the principle goal of microfinance. A market approach which charges poor customers high-interest rates for the sake of profits drifts from the mission of microfinance. Credit institutions that lend to the poor should do it without concern for profit so that they can have the maximum impact in helping the poor climb out of poverty.

Poor rural households in Vietnam need access to affordable credit and social support in order to ensure that their socioeconomic well-being improves. This shows that a poverty alleviation approach may be more appropriate for Vietnam. The income data show that microfinance alone is not enough to reduce poverty. Microfinance is a necessary condition for customers to have the opportunity to create jobs or improve their current employment, increase income, improve skills, and social competence through non-financial activities in microfinance. With the fast changing environment of Vietnam's microfinance industry, the following recommendations are made to enhance the effectiveness of microfinance operations.

\section{Recommendation}

The subprime meltdown in the United States that led to the global financial crisis emphasises the importance of accountability, security, and transparency in financial services. At the same time, the microfinance industry has evolved from its earliest roots as a social movement to a multifaceted financial services industry for the poor. The 
development of new concepts and methodologies are clearly essential in microfinance as it increases the capability of outreach to the poor. When analyzing the credit activities of borrowers, data confirms that almost half of the customers have taken more than one loan. The ease of access with regulation could be dangerous in terms of customers taking on too much debt because organizations do not share information about the borrowers.

Only ten MFIs and two associations have endorsed the Smart Campaign. The Smart Campaign is part of Accion's Center for Financial Inclusion. Its steering committee is comprised of leaders diverse institutions such as the Consultative Group to Assist the Poor at the World Bank, Deutsche Bank Social Investment Group, the World Savings Bank Institute, WWB Colombia, KfW (Germany), Ujjivan (India). CARD Bank (Philippines), the Microfinance Centre (Eastern Europe) and Fonkoze (Haiti). This Campaign promotes the idea of "responsible finance," this means being fully transparent in the pricing, terms, and conditions of all financial products. Currently, no MFI or bank that provides services to the low-income segments in Vietnam fully reports social performance indicators to the MIX Market. MIX Market is an online data platform where financial service providers and supporting organizations globally share institutional data to create transparency and increase market insight. However, two MFIs (TYM and M7-MFI) are making efforts in this regard, and have conducted a social performance rating. Several donors and investors, such as the Asian Development Bank, Agence Francaise de Development, International Finance Corporation, State Secretariat for Economic Affairs, and the World Bank, are currently promoting the adoption of responsible finance principles in Vietnam (IFC, 2013).

\section{Further Research}

Further research based on the findings and limitations of this studying is necessary. There is a need for more primary data in the analysis particularly pertaining to studies of for-profit MFIs in Vietnam. A survey can be conducted focusing on for-profit MFI clients, comparing their situation before joining the MFI to their current situation. A 
survey could also examine the current situation of clients who have switched from a nonprofit MFI to a for-profit MFI. This research would provide a comparison of the impact of organizational structure on the outreach and impact of different financial institutions. As the country moves to a market systems approach to microfinance by 2020 , further research can be conducted on how regulatory environments influence the impacts of commercialization on poor rural households as well. This can be compared to other countries such as Mexico, where regulatory environments are different. Following the suggestions of this research on transparency and data sharing of microfinance in Vietnam, how can cooperation or partnerships between financial institutions and social/informational institutions be made to work? This research would look at how financial technologies can be created. 


\section{Bibliography}

Akerlof, G. (1970), "The market for lemons: Quality uncertainty and the market mechanism." Quarterly Journal of Economics, Vol.84, No. 3, pp. 488-500.

Alter K., (2004), Social Enterprise Typology, Virtue Ventures LLC, Washington, DC. Asia-Pacific Economic Corporation. (2011), "Promoting Sustainable, Market-Based Microfinance: Viet Nam Case Study and Lessons Learned for Apec Economies", APEC USA.

Banerjee, A. V., \& Duflo, E. (2012), Poor economics: a radical rethinking of the way to fight global poverty, New York: PublicAffairs.

Business Insider. (2012, February 24), Hundreds of Suicides in India Linked To Microfinance Organizations. Web.

Carrillo, Ian R. (2009), "The Commercialization of Microfinance in Mexico: Efficiency or Exploitation?" Master's thesis, University of Kansas.

Collins, D., Morduch, J., Rutherford, S., Ruthven, O. (2009), Portfolios of the Poor, How the World's Poor Live on $\$ 2$ a Day.

Copestake, J. (2002), “Unfinished Business: The Need for More Effective Microfinance Exit Monitering." Journal of Microfinance 1-30.

Datar, Srikant, Epstein, M.J., and Yuthas, K. (2008), "In Microfinance, Clients Must Come First", Stanford Social Innovation Review.

Deutsche Bank. (2007), "Deutsche Bank Research”, Frankfurt am Main, Germany. Dieckmann, R. (2007), "Microfinance: an emerging investment opportunity - uniting social investment and financial returns", International Topics, Deutsche Bank Research, Frankfurt, December 19.

Epstein, Marc J., and Yuthas, K. (2014), Measuring and Improving Social Impacts: A Guide for Nonprofits, Companies, and Impact Investors. San Francisco: BerrettKoehler, 2014.

Epstein, Marc J., (2010), "Mission impossible: Diffusion and drift in the microfinance industry", Sustainability, Accounting, Management, and Policy Journal. 
Greene, J and Marshall, R.S. (2010) "ALTIS: A micro-finance start-up in Nepal", Finalist, 2010 oikos Global Case Writing Competition.

Hsu, M.-Y. (2007), "The international funding of microfinance institutions: an overview", ADA-Microfinance Expertise, ADA, Luxembourg, November 23.

Hulme, David, 2000. Impact assessment methodologies for microfinance: theory, experience and better practice. World Dev. 28 (1), 79-98.

International Finance Corporation, IFC. (2013), Responsible Finance in Vietnam.

Karlan, D. and Valdivia, M. (2006), "Teaching entrepreneurship: impact of business training on microfinance institutions and clients", working paper, Yale University Economic Growth Center, Yale.

Luan, D. X., \& Bauer, S. (2016). Does credit access affect household income homogeneously across different groups of credit recipients? Evidence from rural Vietnam. Journal of Rural Studies, 47, 186-203.

Mishkin, F.S. (2001), The Economics of Money, Banking and Financial Markets (6th Ed.) Addison-Wesley.

McKernan, S.-M. (2002), "The Impact of Micro Credit Programs on Self- Employment Profits: Do Non-Credit Program Aspects Matter?" this REVIEW 84, 93-115.

Ngo, Trong V. (2012), "Capital Structure and Microfinance Performance A Cross-Country Analysis and Case Study of Vietnam", PhD. Thesis, University of Birmingham.

Nguyen, Kim Anh, Van Thu, Ngo, Thanh Tam, Le, Mai, Nguyen Thi Tuyet. (2011), Microfinance versus Poverty Reduction in Vietnam-diagnostic Test and Comparison.

Nguyen, Viet Cuong. (2008), Is a governmental micro-credit program for the poor really pro-poor? evidence from Vietnam. Dev. Econ. 46 (2), 151-187.

Olivares-Polanco, F. (2005), "Commercializing microfinance and deepening outreach? Empirical evidence from Latin America", Journal of Microfinance, Vol. 7 No. 2, pp. 47-70.

Paulson, A. L., and Townsend, R. (2004), "Entrepreneurship and Financial Constraints 
in Thailand," Journal of Corporate Finance 229-262.

Polak, P. (2009), Out of poverty: what works when traditional approaches fail, San Francisco: Berrett-Koehler.

Polak, P., \& Warwick, M. (2013), The business solution to poverty: designing products and services for three billion new customers, San Francisco: Berrett-Koehler.

Quach, Manh Hao. (2005), "Access to Finance and Poverty Reduction: an Application to Rural Vietnam", Master's thesis, University of Birmingham.

Reynolds, Mary A., and Yuthas, K. (2008), "Moral Discourse and Corporate Social Reporting", Journal of Business Ethics, 78(1-/2): 47-64.

Rhyne, E. (1998), "A The Yin and Yang of Microfinance: Reaching the Poor and Sustainability", The Microbanking Bulletin, No. 2, pp. 6-8.

Robinson, M.S. (2001), The microfinance revolution: Sustainable finance for the poor, the World Bank.

Vietnam Microfinance Working Group, MFWG. (2014), "2014 Annual Report A 10-year Journey", Hanoi: Vietnam Microfinance Working Group.

Vietnam Microfinance Working Group, MFWG. (2014), "Microfinance in Vietnam: The real situation and policy recommendations", Hanoi.

World Bank, W.B. (2007), Developing a Comprehensive Strategy to Expand Access for the Poor to Microfinance Services, Vol. I.

World Bank, (2017, April 13), Vietnam Overview. Web.

Yunus, M. (2003), Banker to the Poor: Micro-Lending and the Battle Against World Poverty. New York: Public Affairs.

Yunus, M. and Weber, K. (2007), Creating a World without Poverty: Social Business and the Future of Capitalism, New York: PublicAffairs.

Yunus, M. and Weber, K. (2011), Building social business: the new kind of capitalism that serves humanity's most pressing needs, New York: Public Affairs. 